\title{
Physical and Non-Physical Factors Measurement of the Indoor Thermal Environment
}

\author{
Anggana Fitri Satwikasari \\ Department of Architecture \\ Universitas Muhammadiyah Jakarta \\ Jakarta, Indonesia
}

\author{
Luqmanul Hakim \\ Department of Architecture \\ Universitas Muhammadiyah Jakarta \\ Jakarta, Indonesia
}

\begin{abstract}
Based on several previous studies, measurement of climate factors such as Temperature (T), Relative Humidity (Rh), Air Velocity (v), and solar radiation, that has been known as phyiscal factor of micro climate, used to be referred as the standard of thermal comfort. However, based on the ASHRAE / ANSI 55 standard, thermal comfort level is also determined by non-physical measurements of the subjective evaluation from occupants. In this study, both of physical and non-physical measurement methods were carried out to see the differences of them on two modified classrooms which one of them has additional void and indoor garden. We use anemometer and environmeter to measure the physical factors of the micro climate inside the modified rooms. Meanwhile, we gave likert scaled questionaire to 23 respondents, who are the students that have similar activities throughout years, as the non-physical measurement. The results showed that eventhough the physical factors measurement is not significantly different, the nonphysical factors from the questionaire showed a big gap. Out of the 23 respondents, more than $50 \%$ said that the thermal comfort was better in a room that has additional voids and indoor plants.
\end{abstract}

Keywords - Thermal Comfort; Physical Factors; Non-Physical Factors; Voids.

\section{INTRODUCTION}

Indonesia is a tropical country that has high anual humidity and rainfall during the monsoon. Meanwhile, during the drought season, high temperature will be measured in several cities, especially in Jakarta. As the capital city, Jakarta is the main destination for urbanization from other smaller cities. It caused the availability of land for residential purposes have decreased. This is also a main reason why this city is dominated by low-rise until high-rise as the solution for the lack of landed house.

New problem has arrised as some the occupants in low-rise building, such as two or third floor house, stated that they feel stuffiness and overheat inside their house. It happened because of the ventilation system didn't function properly and forces them to buy additional fan or air conditioner to stabilize the indoor temperature that also cost them a lot.

When a person stay inside a room they will experience a state of thought that expresses satisfaction over a building's thermal environment which is affected by micro climate change surround it, usually known as Thermal Comfort [1]. There is no exact explanation to state which The feeling of satisfaction of dissatisfaction with the indoor air quality (IAQ) can be related with the thermal environment quality. FH Rohles [2] explained that thermal environment is considered to contain six variables, namely dry-bulb temperature, relative humidity, mean-radiant temperature, air movement, people’s physical activity (metabolism), and clothing. He also explained in his paper [2] how the condition of mind, that could be affected by external factors, will determined the subjective evaluation and the acceptability of the thermal comfort. He concluded that a person's condition of mind can be altered by minor and apparent insignificant variations in the environment. To establish design criteria, designer must determine the comfort envelope and the thermal conditions.

IAQ, which is consist of thermal environment as well, can be influenced by physical and non-physical factors surround. Physical factor is referred to every micro climate parameter, while the non-physical factors can be described as every parameters coming from human aspects (e.g: health status, lifestyle, daily activity, human perception, human opinion, etc). It is supported by Satwikasari [3][4] who explained that Windows-to-Wall Ratio (WWR) is proved to affected the occupant's health state as the most of Tuberculosis patient was found out didn't have proper and ideal percentage of WWR. In that research, she stated that aside of physical factos, the nonphysical factors, which is referred to the human's health state that described in questionaire form, also took a big part in IAQ assessment.

This research aim to explain how the measurement of physical and non-physical factors of thermal environment may be different. Similar research has been done by Luo et al [5] who aim to investigated the relationships between occupants' indoor thermal experience and their thermal comfort perception.They concluded that people's indoor thermal experiences will affect their understanding of thermal comfort. In othe word, occupants will be easier and quicker to get accustomed to the thermally neutral lifestyle than it is for 'spoiled' occupants to lower their expectations and adapt to non-neutral indoor climate.

Those prior researches motivated us to do a semiexperimental on low-rise building to assess the thermal comfort of two modified sample rooms in low-rise building. This research used two classrooms, later will be written as classroom " $A$ " and " $B$ ", in Department of Architecture Universitas Muhammadiyah Indonesia located in Jakarta, which had been modified by adding $80 \mathrm{~cm}$ x $120 \mathrm{~cm}$ void in classroom " $A$ " and put some indoor plants in the same exact spot of the both classrooms. The physical factors assessment will be done for the Temperature (T), Relative Humidity (Rh), and Air Velocity (v) of both rooms. While the non-physical factors, will be referred to human's perception using bedford thermal comfort standard, will be gained from bedford scale questionaire. 
Void and indoor garden are the sample of passive design that may be used to increase the ventilation and temperature quality of the room [6]. The result of the field assessment and analytical process will be furtherly explained in third chapter to show the clear comparation of the both thermal environment factors measurement.

\section{METHODS}

This research will be emphasized on the influence of voids and interior gardens, especially plants, for indoor thermal comfort in two modified rooms. The effect of those modifications will be seen with the physical and non-physical factors measurement and will be further explained with descriptive methods.

A. Deciding the Sample Rooms and 4 Modification Types

The chosen rooms are Department of Architecture Universitas Muhammadiyah Jakarta (UMJ)'s Building Technology Laboratory (Room "A") and The Architectural Student Community (Room "B"). The both sample rooms originally have the same exact dimension and ventilation inletoutlet (e.g: door and window size, door and window amount) (Fig. 1). It shows that both rooms have the same Air Velocity (V), Temperature (T), and Relative Humidity (Rh). Before the measurement process, a void sized $80 \mathrm{~cm}$ x $120 \mathrm{~cm}$ has been installed with in the room " $\mathrm{A}$ ", while the room " $\mathrm{B}$ " will be left as its original (Fig. 2).

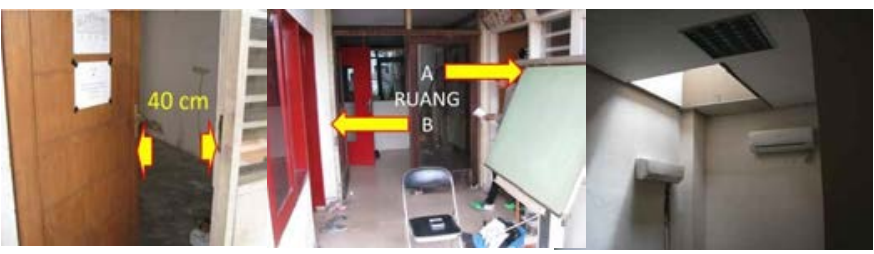

Fig. 1. (Left) The Door Opening Distance For Each Modified Room To Maintain The Existing Air Velocity (v) From The Outdoor; (Center) The Corridor Outside the Modified Rooms; (Right) The Additional Void Built in the Room A

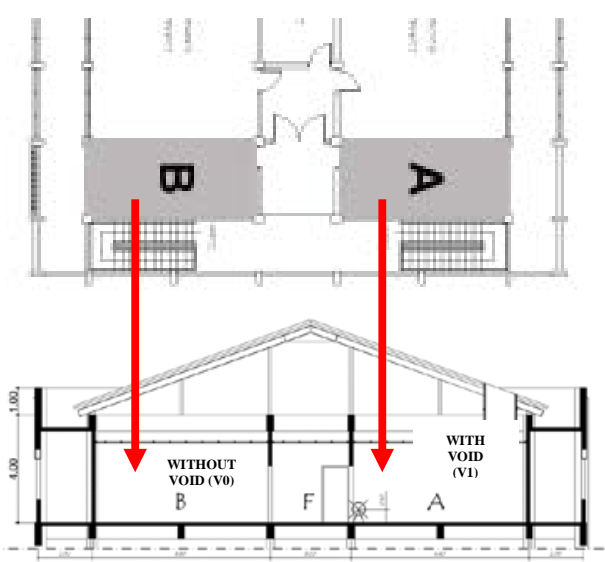

Fig. 2. The Floor Section Of The 3rd Floor Department Of Architecture Universitas Muhammadiyah Jakarta (UMJ)
In the Room A, the modification would be "V1IG0" (With Void, Without Indoor Garden) and "V1IG1" (With Void, With Indoor Garden), meanwhile in the room B, the modification were "V0IG0" (Without Void, Without Indoor Garden) dan "V0IG1" (Without Void, With Indoor Garden), as V is refer to 'Void', IG is refer to 'Indoor Garden', and the following number means 'existed' for ' 1 ' and 'not-existed' for '0' (Fig. 3).
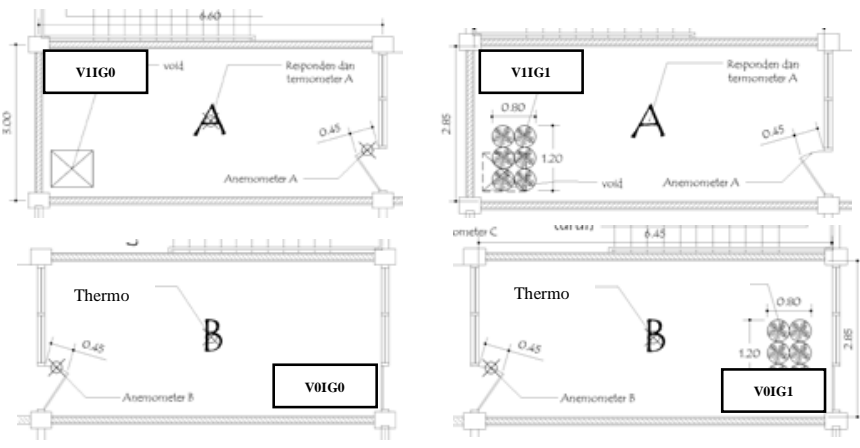

Fig. 3. The Floor Plan of Two Modified Rooms with 4 Types of Modifications

\section{B. Selecting the Respondents}

The chosen 26 respondents were the Department's students who have been assumed living in the same thermal environment and have similar activity throughout years. They must have been very familiar with the comfort level of the both sample rooms. But, none of them have entered the room after being modified with void and indoor garden.

\section{Measurement and Analysis Tools}

The Thermal Environment's parameters considered as physical factors are Temperature (T) and Air Velocity (v). To measure those variables, Environmeter and Anemometer were being used. Meanwhile, the students was asked to filled the questionaire that have been had Bedford Comfort Level (S) option and open-ended question for their additional opinion, if any. After all the data have been gained, researcher compiled and clasified the data into result tables and interpreted it with descriptive methods.

\section{RESULT AND DISCUSSION}

\section{A. Physical Measurement of Thermal Environment and Bedford Comfort Level}

As can be seen in Fig.4, there is a significant difference in Air Velocity (V) between Room " $\mathrm{A}$ " and Room " $\mathrm{B}$ ". The higher Air Velocity happened more often in Room " $A$ " than the Room " $B$ ". It means that there was better air circulation happened in room " $A$ " after got more air flow from the void. 


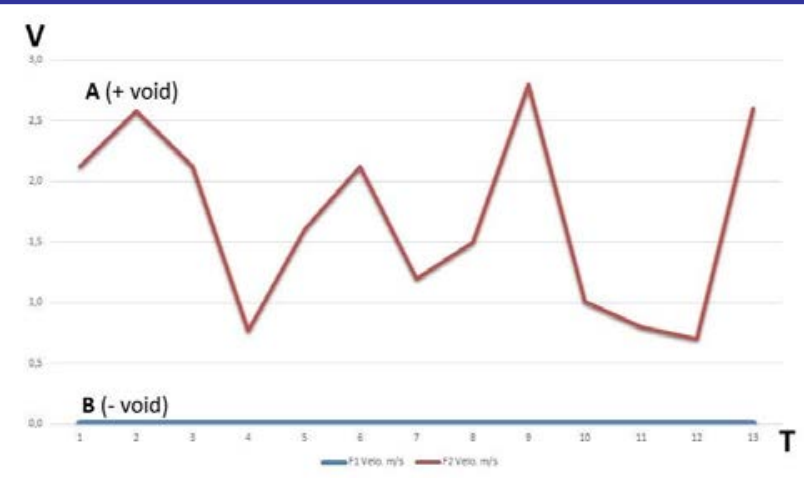

Fig. 4. Air Velocity (v) Measurement Graphics

It can be seen in the Fig 5, that there is a significant difference between the mean temperature in the room " $A$ " and " $B$ ". After being added with void, in a certain measurement period, the temperature in the room " $A$ " decreased. The fluctuative change didn't happen in the room " $B$ " which didn't have additional air inlet such as in the room " $\mathrm{A}$ ".

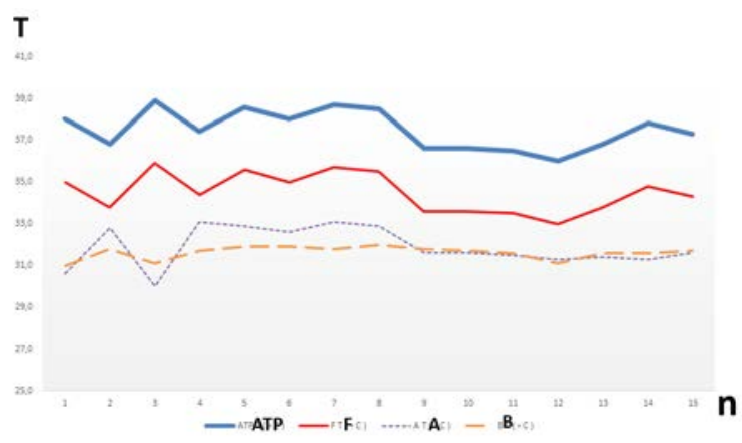

Fig. 5. Temperature (T) Measurement Graphics

Later, the resume of the measurement in the 4 modification situations, will be explained in the following:

1. (S) V0IG0 , the room temperature (T) recorded at an average of $31.5^{\circ} \mathrm{C}, \mathrm{v}=0 \mathrm{~m} / \mathrm{s}$, and $\mathrm{RH}=60.9 \%$, with the comfort level at an average of 29.2.

2. (S) V0IG1, the room temperature (T) recorded at an average of $31.6^{\circ} \mathrm{C}, \mathrm{v}=0 \mathrm{~m} / \mathrm{s}$, and $\mathrm{RH} 60.1 \%$, with the comfort level at an average of 29.3.

3. (S) V1IG0 , the room temperature (T) recorded at an average of $31.6^{\circ} \mathrm{C}, \mathrm{v}=1.9 \mathrm{~m} / \mathrm{s}$ and $\mathrm{RH} 54.8 \%$, with the comfort level at an average of 28.2.

4. (S) V1T1, the room temperature (T) recorded at an average of $32.0^{\circ} \mathrm{C}, \mathrm{v}=1.6 \mathrm{~m} / \mathrm{s}$ and $\mathrm{RH} 56$ 6\%, with the comfort level at an average of 28.2.

With those number, it showed that the Bedford thermal comfort (S) for the experimental room B without void (V0) is at 29.25. While for room A that have Void (V1) is at number 28.2. Based on the same analysis, Bedford thermal comfort (S) at V0IG1 has 0.1 points higher that V0IG0. This indicated that the existence of Indoor garden (IG) in a room that didn't has void (V0), affected the thermal comfort. However, in another room that has a void, the number of (S) didn't has differences, yet it was the best number among others. In conclusion, the
Bedford thermal comfort (S) will be better in a room with a void than a room without void and Indoor garden.

\section{B. Non-Physical Measurement of Thermal Environment}

By using Bedford Comfort Level, the questionaire consists of seven comfort parameters was given to the 26 respondents. They filled it together at the same time so we can validate the result afterwards. The resume of their perception can be seen in the Fig 6 below.

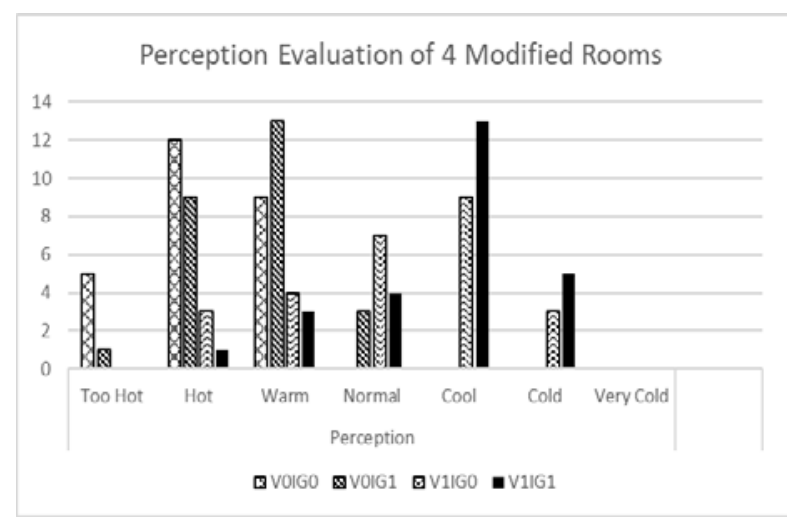

Fig. 6. The Perception Evaluation of 26 Students as Non-Physical Measurement of Thermal Environment.

The respondents who entered the V0IG0 room only felt the 'warm', 'hot', and 'too hot' sensation during the research periods, while in the room with additional indoor plants (V0IG1), 3 people felt the heat was reduced since they could feel the room is getting shadier by the plants and they said the comfort level or their perception of the room was 'normal'.

In the room V1IG0, no one said that the room was 'too hot' anymore, even 3 people felt the room was 'cold' and they would like to stay longer since the room was getting more comfortable although without any indoor plants. It could be caused by many aspects. One of them might be because they were too often have activities in stuffy room (Room " $\mathrm{B}$ ", without void) and when the got chance to feel a 'better' room with better air circulation, they tend to feel more satisfied with the new one.

Meanwhile, in the room with V1IG1 condition, respondents felt 5 kind of comfort level and almost $50 \%$ of them said the room was 'cool'. Aside from the presence of additional void, this modified situations has indoor plants to decrease the temperature by its characteristics. The role of the plants here is to give more oxygen for the occupants and made the room shadier, so the solar radiation thay might entered the building or the room from its ventilation or openings, could be blocked.

\section{CONCLUSION}

After two prior researches [7][8], , the presence of voids (V1) has a profound effect to increase the thermal comfort [6]. The additional air inlet-outlet that could have been obtained from the additional void has created a great impact for the human's comfort and increased the quality of indoor thermal environment. For the low-rise buildings, adding more air inlet with voids might be a great solution to enhancing the thermal environment quality and improve the occupants' health state. 


\section{ACKNOWLEDGMENT}

We would like to thank LPPM Universitas Muhammdiyah Jakarta (UMJ) that supported this research funding, to the Department of Architecture UMJ, and also Faculty of Engineering UMJ for giving us chance to did this research and use the facilities within.

\section{REFERENCES}

[1] ASHRAE Standard 55-thermal environmental conditions for human occupancy, ASHRAE Inc., 1992, Atlanta

[2] Rohles Jr, Frederick H., "Temperature and Temperament: A Psychologist Looks at Comfort”. ASHRAE Journal February, 2007, Pg. $14-22$

[3] Satwikasari, Anggana Fitri, Penilaian Kualitas Lingkungan Fisik Permukiman yang Berpengaruh terhadap Prevalensi Tuberkulosis (TB). Studi Kasus: Kabupaten Kebumen, Jawa Tengah, 2015, Tesis S2 Arsitektur Institut Teknologi Bandung.

[4] Satwikasari, Anggana Fitri, "Pengaruh Prosentase Windows-To-Wall Ratio (WWR) Terhadap Kualitas Kesehatan Penghuni. Studi Kasus: Rumah Penderita Tuberkulosis (TB) Di Kebumen”. Prosiding Semnastek 2017.

[5] Luo, Maohui., "Indoor climate experience, migration, and thermal comfort expectation in buildings", Building and Environment Journal, August 2018, Vol 141, pg. 262-272, https://doi.org/10.1016/j.buildenv.2018.05.047

[6] Satwikasari, Anggana Fitri et al., "Enhancing Thermal Environment Quality With Void And Indoor Garden As Passive Design Strategy Towards Sustainable And Healthy Living”, article in press.

[7] Hakim, Luqmanul., "Pengudaraan Silang Pada Pengembangan Rumah Sederhana”, NALARs Volume 8 Nomor 1 Januari, 2009, pg:1-19.

[8] Hakim, Luqmanul et al., "Efektifitas Void Pada Pengudaraan Silang Untuk Kenyamanan Di Dalam Ruang”, Jurnal Arsitektur NALARs Volume 14 No 2 Juli, 2015, pg:131-144. 